\title{
Expanding walls and shrinking beaches: Loss of natural coastline in Okinawa Island, Japan
}

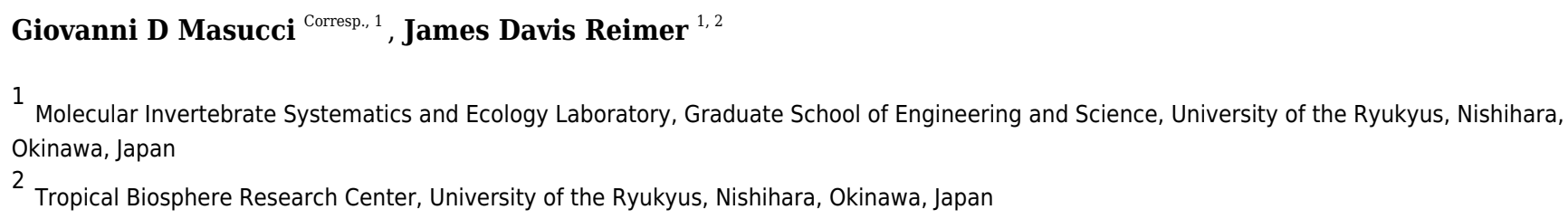

Okinawa is the largest and most populated island of the Ryukyu Archipelago in southern Japan and is renowned for its natural resources and beauty. Similar as to what has been happening in the rest of the country, Okinawa Island has been affected by an increasing amount of development and construction work. The trend has been particularly acute after reversion to Japanese sovereignty in 1972, following 27 years of post-war American administration. A coastline once characterized by extended sandy beaches surrounded by coral reefs now includes tracts delimited by seawalls, revetments, and other human-made hardening structures. Additionally, part of coastal Okinawa Island was obtained by landfilling shallow ocean areas (land reclamation). Nevertheless, the current extension of the artificial coastline, as well as the level of fragmentation of the natural coastline are unclear, due to the lack of both published studies and easily accessible and updated datasets. The aims of this research were to quantify the extension of coastline alterations in Okinawa Island, including the amount of land-filling performed over the last 51 years, and to describe the coastlines that have been altered the most as well as those that are still relatively pristine. The analyses were performed using a reference map of Okinawa Island based on GIS vector data extracted from the OpenStreetMap (OSM) coastline dataset (average node distance for Okinawa Island $=24 \mathrm{~m}$ ), in addition to satellite and aerial photography from multiple providers. We measured $431.8 \mathrm{~km}$ of altered coastline, equal to about $63 \%$ of the total length of coastline in Okinawa Island. Habitat fragmentation is also an issue as the remaining natural coastline was broken into 239 distinct tracts (mean length $=1.05 \mathrm{~km}$ ). Finally, $21.03 \mathrm{~km}^{2}$ of the island's surface were of land reclaimed over the last 51 years. The west coast has been altered the most, while the east coast is in relatively more natural conditions, particularly the northern part, which has the largest amount of uninterrupted natural coastline. Given the importance of the ecosystem services that coastal and marine ecosystems provide to local populations of 
subtropical islands, including significant economic income from tourism, conservation of remaining natural coastlines should be given high priority. 


\section{Expanding walls and shrinking beaches: Loss of natural 2 coastline in Okinawa Island, Japan}

3 Authors: Giovanni D. Masucci ${ }^{*}$, James D. Reimer ${ }^{1,2}$

$4 \quad{ }^{1}$ Molecular Invertebrate Systematics and Ecology Laboratory, Graduate School of Engineering 5 and Science, University of the Ryukyus, Nishihara, Okinawa, Japan.

$6 \quad{ }^{2}$ Tropical Biosphere Research Center, University of the Ryukyus, Nishihara, Okinawa, Japan 7

8 Corresponding Author:

9 Giovanni Masucci

10 E-mail address: giovannimasucci@me.com

111 Senbaru, Nishihara, Okinawa, 903-0213, Japan.

12 Phone number: +815058098703 


\section{Abstract}

14 Okinawa is the largest and most populated island of the Ryukyu Archipelago in southern Japan

15 and is renowned for its natural resources and beauty. Similar as to what has been happening in

16 the rest of the country, Okinawa Island has been affected by an increasing amount of

17 development and construction work. The trend has been particularly acute after reversion to

18 Japanese sovereignty in 1972, following 27 years of post-war American administration. A

19 coastline once characterized by extended sandy beaches surrounded by coral reefs now includes

20 tracts delimited by seawalls, revetments, and other human-made hardening structures.

21 Additionally, part of coastal Okinawa Island was obtained by land-filling shallow ocean areas

22 (land reclamation). Nevertheless, the current extension of the artificial coastline, as well as the

23 level of fragmentation of the natural coastline are unclear, due to the lack of both published

24 studies and easily accessible and updated datasets. The aims of this research were to quantify the

25 extension of coastline alterations in Okinawa Island, including the amount of land-filling

26 performed over the last 51 years, and to describe the coastlines that have been altered the most as

27 well as those that are still relatively pristine. The analyses were performed using a reference map

28 of Okinawa Island based on GIS vector data extracted from the OpenStreetMap (OSM) coastline

29 dataset (average node distance for Okinawa Island $=24 \mathrm{~m}$ ), in addition to satellite and aerial

30 photography from multiple providers. We measured $431.8 \mathrm{~km}$ of altered coastline, equal to about

$3163 \%$ of the total length of coastline in Okinawa Island. Habitat fragmentation is also an issue as

32 the remaining natural coastline was broken into 239 distinct tracts (mean length $=1.05 \mathrm{~km}$ ).

33 Finally, $21.03 \mathrm{~km}^{2}$ of the island's surface were of land reclaimed over the last 51 years. The west

34 coast has been altered the most, while the east coast is in relatively more natural conditions,

35 particularly the northern part, which has the largest amount of uninterrupted natural coastline.

36 Given the importance of the ecosystem services that coastal and marine ecosystems provide to

37 local populations of subtropical islands, including significant economic income from tourism,

38 conservation of remaining natural coastlines should be given high priority. 


\section{Introduction}

Japan is renowned worldwide both for its economic, industrial, and technological achievements, and for its cultural and natural heritage. Unfortunately, a consequence of the Japanese development model has been the destruction of portions of the country's natural environments, both terrestrial and marine (McCormak 1999, Kerr 2001). After World War II, Japan has increasingly invested public money in projects related to modifications of the natural landscape (Walker and Mossa 1986). This included the alteration of 110 out of its 113 major rivers with numerous dams and concrete enclosures, in addition to minor streams across the country, and the creation of numerous mountain roads for the forestry industry, which has contributed to the eradication of around 40\% of Japan's native forest (Kerr 2001). During the 1990s, the production of concrete in Japan rose, reaching the highest cement consumption per capita in the world and the highest per capita construction-related debt (¥8 million; Kingston 2005). This increase was seemingly unaffected by the recession that the country was facing, which, instead, accelerated the production: between 1992 and 1999, the country invested $¥ 120$ trillion to boost the economy, of which $\sim 60 \%$ was spent on construction projects (Kingston 2005), producing as much concrete per year as the United States (Kerr 2001; Kingston 2005). During this time, local and international commenters began describing Japan as the 'doken kokka', the construction state (McCormack 1999; Kerr 2001; Kingston 2005; Nam 2019).

Perhaps the most well-known and evident impact of construction can be seen on the coastline, where numerous civil engineering projects have been performed, either by the placement of bulkheads, seawalls, breakwaters, revetments, and groins, with the purpose of protecting human-made buildings and coastal roads from erosion and wave action (shoreline hardening, or armoring), or by extending the coastline seaward by filling the ocean with soil, rocks, cement, or combinations of these materials, in a process known as "land reclamation" or "land-filling". Both of these expressions are not without issues: the term "land reclamation" has also been associated with a wide range of human-made alterations, generally with the aim of converting disturbed land to productive uses (Powter 2002). In a similar way, the term "landfilling" overlaps with the practice of disposing garbage by burial on land. In the context of this research, the meanings of the two expressions are identical, but we here use the more neutral and descriptive "land-filling". 
69

70 71 72 73 74

When a coastline is eroding, coastal armoring can interfere with natural beach upslope migration, triggering a passive erosion of the shoreline that can lead to beach narrowing or loss (Griggs, Tait and Corona 1994; Dugan et al. 2008), a phenomenon which has been defined as "coastal squeeze" (Doody 2004). In terms of impacts on the marine ecosystems, shoreline hardening reduces habitat complexity and uniqueness, affecting species composition, and decreasing abundance and diversity (Seitz et al. 2006; Dugan et al. 2008; Gittman et al. 2016; Aguilera 2017). The effects of land-filling the marine environment include habitat loss (Lai et al. 2015; Heery et al. 2018) and a degradation of environmental parameters levels, particularly higher nutrients, sedimentation rates, and turbidity, which can negatively impact the survival of coral reefs (Chou, Yu and Loh 2004; Dikou and van Woesik 2006).

Japan’s “Environmental Impact Assessment (EIA) Law” was enacted in 1997 and implemented in 1999, providing legal power to deny authorization to construction projects exerting excessive impacts on the environment (Ministry of the Environment of Japan 2019). Although an important achievement, the law has some limitations that need to be considered. Only large-scale construction projects require EIAs. For medium-scale works, the necessity of an EIA is judged by the national government for each individual project, while smaller-scale projects do not require any assessment by national law. In the case of land-filling, an EIA is only required for projects involving over 50 ha $\left(0.5 \mathrm{~km}^{2}\right)$ of reclamation. For land-fills between 40 and 50 ha $\left(0.4-0.5 \mathrm{~km}^{2}\right)$, the decision is taken on a per-project basis, and below $40 \mathrm{ha}\left(0.4 \mathrm{~km}^{2}\right)$ there is no requirement. If the reclamation is performed to build harbors and ports, the limit for no EIA is extended to 300 ha $\left(3 \mathrm{~km}^{2}\right)$. Although the size of a project is an important factor, it is not the only one: EIA only regulates specific categories of construction works. While land-filling is one of the covered categories, coastal armoring is not included and can therefore proceed without any EIA (see Ministry of the Environment of Japan (2019) for a detailed list of categories and sizes subject to EIA Law).

EIAs are performed by the project proponent and sent to an authorizing agency (commonly the Ministry of Infrastructure, Land and Transport, or the Ministry of Economy, Trade and Industry), which makes the final decision. Because the authorizing agency and the proponents can share similar interests, the Ministry of the Environment (MoE) can be requested to express an opinion. However, a positive MoE opinion is not required for the final approval. 
Finally, there is no requirement for follow-up surveys that would provide data on the quality of the initial EIA and on the impacts of the construction work on the natural environment (Ministry of the Environment of Japan 2019). This is one of the reasons why the impacts on the natural environment of coastal construction projects in Japan are generally unreported, and thus unclear or unknown. EIAs are not the only legislative instruments that regulate construction works; in the case of land-filling, a permit from the local government is needed, making the role of prefectural governors important in the final decision (Okinawa Prefectural Government 2014; Ministry of Land, Infrastructure and Transport of Japan 2001).

The Ryukyus (also Nansei Islands), a subtropical archipelago located in southwestern Japan, consist of approximately 160 islands. They include the most extensive coral reefs of the country, hosting almost $90 \%$ of the scleractinian coral species found in Japan ( $\sim 360$ species out of 415; Nishihira 2004), and have high levels of marine diversity and endemism (Cowman et al. 2017). Okinawa Island, or Okinawa-jima in Japanese (Fig. 1), is the largest and most populated island in the archipelago $\left(\right.$ area $=1208 \mathrm{~km}^{2}$; Japan Statistics Bureau 2014; population $=1.3 \mathrm{M}$ people; Okinawa Prefectural Government 2019a). has provided significant economic income from tourism, and there has been a rapid growth in the number of visitors in recent years, surpassing those of Hawaii in 2017 (total number = 9,579,900 visitors; Ryukyu Shimpo 2018). However, the natural environment has also been damaged by human activities, including deforestation, urban sprawl, coastal development, coastal hardening, and land-filling (McCormack 1999; Nakano 2004; Reimer et al. 2015; Heery et al. 2018). projects have profoundly modified and reshaped the island landscape and topography (McCormack 1998; McCormack 1999; Kerr 2001). By 1992, more than 1600 ha of reef had been destroyed due to land-filling and dredging, roughly equal to the $6 \%$ of the total coral cover around the island (Nakano 2004). The high influx of tourists has contributed to the building of new infrastructure along the coastline and on reclaimed land (McCormack 1998; Tada 2015). Despite the difficulties in estimating general trends and local impacts due to the lack of post-

127 work assessments and published studies, construction has been pursued to such an extent that 128 civil engineering has been described as the main cause of coral reef destruction in the region 129 (Nakano, 2004). Today, the development in Okinawa Island continues and, as of January 2019, 
130 three major land-filling projects are underway: the construction of a second runway at Naha 131 Airport (1.6 km² of reclaimed land; Flyteam Japan 2013), the creation of a harbor, residential

132 facilities, resorts, and artificial beaches at the Awase Tidal Flats (2.66 km²; Nakano 2004), and

133 the building of a new US military base at Cape Henoko/Oura Bay $\left(1.6 \mathrm{~km}^{2}\right.$; Okinawa Defense 134 Bureau 2012).

135 In this research, using GIS software and remote sensing technologies, specifically

136 satellite imagery and aerial photography, we described the current state of the Okinawa Island 137 coastline, with three main objectives:

138 1) To quantify the amount of coastline that has been altered as of the end of 2018 , and to 139 categorize such alterations. This included a comparison between the east and west coasts, as we hypothesized higher levels of impact and habitat fragmentation on the west side of the island, due to the presence of the capital and largest city Naha and of National Route 58 , a coastal road constituting the main connection between the north and south of Okinawa Island.

2) To generate a map allowing easy visualization of the current status of the island coastline, including habitat fragmentation, and to identify which parts of the island have lost the largest amounts of natural coastline, and which locations have the highest amount of preserved coastal environment.

3) To determine the amount (area) and locations of land-filling performed during the last 51 years of Japanese administration of Okinawa Island (1977-2018).

Both the maps generated in this study and the underlying dataset provide a baseline for future studies and can be used as an additional tool when performing evaluations on projects potentially impacting the island's natural coastal environments.

\section{3}

Materials \& Methods

According to a survey conducted by the Japanese Coast Guard in 1986 (Japan Statistics Bureau 2014), Okinawa Island has $476 \mathrm{~km}$ of coastline. However, there are two issues with this number. Firstly, the extension of a coastline is not fixed in time and can be affected by natural factors, like erosion or, at shorter time scales, by human activities, including coastal hardening and land-filling. Secondly, the extension of a coastline depends on the scale at which the measurements are done. The more detailed the scale of a map, the longer the measured coastline 
160 will be, tending towards infinite (coastline paradox; Richardson 1961; Mandelbrot 1967), with

161 no clear-cut gap between what is useful and unrequired detail. Because coastlines are fractals

162 with properties of self-similarity, it is not possible to state the length of a coastline without

163 referring to a specific reference map or to a scale and accuracy of unit of measurement. In other

164 words, numbers referring to the length of a coastline that do not report this additional

165 information are of little use (Mandelbrot 1967).

166 For these reasons, to assess the amount of altered coastline in a way that will make

167 possible for future studies to make comparisons at different times or with other locations, our

168 measures were performed over a base layer of LineString data (polylines vectors connecting

169 georeferenced points) extracted from the OpenStreetMap (OSM) coastline dataset (Haklay and

170 Weber 2008) at maximum detail (visualized at a scale of 1:1000, WGS-84/long datum, dataset

171 acquired on January 26, 2019). OpenStreetMap data provide key advantages compared to

172 datasets from numerous other sources: 1) They are easily accessible and can be freely used for

173 research purposes, 2) they are constantly updated, allowing to conduct repeated surveys over the

174 years to monitor trends and changes in the coastlines, and 3) they are not specific to one country

175 or region, which means that they can be used for future comparisons with other islands or

176 coastlines.

177 The OpenStreetMap coastline dataset (tag: natural=coastline) includes worldwide vector

178 data delineating the sea edge, which is marked by the mean high water spring line. Coastline

179 information is acquired from satellite data (such as NASA Landsat; see

180 https://wiki.openstreetmap.org/wiki/Potential_Datasources\#Shoreline_databases for a

181 comprehensive list) and automatically converted into vectors using automatic image recognition

182 algorithms. The acquired vector lines are then quality-checked and refined by the members of the

183 OSM community. Being a vector dataset, scale (or spatial resolution) is represented by the

184 average distance between nodes (GFC, Kansas State University 2019). In the OSM coastline

185 dataset, average node distance varies with location on a scale that goes from tens to a few

186 hundreds of meters. Node density is particularly high in Europe and Japan, and lower where

187 baseline data are more inaccurate and local contributors are fewer, such as Antarctica. Overall,

188 the average global spatial resolution of the OMS dataset has been measured at $66 \mathrm{~m}$ (Hormann

189 2013). Coastal generalization algorithms may be used when comparing regions of the world with

190 different spatial resolution. 
The base layer of the Okinawa coastline was imported into QGIS (version 3.6.0-Noosa;

192 QGIS Development Team 2019) and updated with minimal modifications to take into account

193

194

195

196

197

198

199

200

201

202

203

204

205

206

207

208

209

210

211

212

213

214

215

216

217

218

219

220

221

new and ongoing land-filling works not yet indexed by the OSM project, including Naha Airport, Awase, and Oura Bay/Henoko. The total coastline included Okinawa Island and artificial landfills connected to the main Island. Naturally occurring islands connected via bridges to Okinawa Island were not included. However, natural islands that became merged via land-fills were included in the analyses. The total coastline was then divided into west and east coasts using the northernmost $(\mathrm{GPS}=26.875525,128.257702$, Cape Hedo) and southernmost (GPS = 26.074467, 127.676570, Cape Arasaki) points of the island, to allow comparisons between the two. Altered portions of the Okinawan coastline were tagged over the base map layer with the help of satellite data and aerial photography from ESRI, Google, Bing, and the Okinawa Prefectural Government historical GIS dataset. Where image data were unclear, observations from the 5 th basic survey on conservation of the natural environment from the Biodiversity Center of Japan, Ministry of the Environment (1998) were referenced. Finally, visits to locations to confirm information were conducted as needed. Collectively, these sources allowed us to draw a map reflecting the situation of Okinawa Island at the end of year 2018. The altered coastline was obtained by tracing LineStrings over the base layer and tagging them accordingly within defined 'alteration' categories. This process was done using the GIS software Map Plus for iOS (version 2.8.5, Duwei Technology 2019).

Each coastline LineString was included into one the following alteration categories (Fig. 2):

1. Natural. The shore (beach or rocky shore) and the terrestrial area immediately behind the shore have been preserved, allowing the existence of a buffer zone made by vegetation and/or dunes.

2. Soft armoring. The shore has been hardened by walls or other human-made constructions. Hardening blocks are on land and the components of the natural coastline (vegetation, sand, intertidal zone, etc.) are still preserved.

3. Hard armoring. The shore has been hardened by seawalls, breakwaters, or other humanmade constructions, placed into the water and/or at the interface between water and land. One or more components of the former natural coastline have been compromised by something human-made (roads, seawalls, coastal buildings, breakwaters, etc.), so that simply removing the hardening would not restore the natural coastline.

Peer) reviewing PDF | (2019:05:38025:1:1:NEW 10 Jul 2019) 
222

223

224

225

226

227

228

229

230

231

232

233

234

235

236

237

238

239

240

241

242

243

244

245

246

247

248

249

250

251

4. Land-filling. A tract of hardened coastline obtained from human-made land reclamation of the intertidal and, in some cases, subtidal zones.

It is important to note that both the map of human-made alterations and the underlying data are conservative, mainly due to two reasons. First of all, it is possible, especially in the case of soft armoring, for vegetation to grow around barriers, making them hard to confirm from satellite images. Secondly, blocks placed in the subtidal zone and completely submerged, although used in Okinawa Prefecture, could not be accounted for in our analyses as they were not reliably visible in satellite images.

LineStrings were grouped in their respective categories and imported into QGIS, where their length in kilometers was summed to obtain the total lengths $(\mathrm{km})$ of each group and the percentages of each category on the total coastline. Moreover, in order to examine coastline fragmentation and the relative contributions to fragmentation (assuming all coastline was originally natural) from each coastal category above, the number of LineStrings and LineStrings mean length were calculated for the natural coastline, for the whole altered coastline, and within each category of alteration.

Descriptive statistics were performed using R software (version 3.5.3; R Development Core Team 2019). As the dataset included the totality of LineStrings composing the Okinawa coastline, no statistical test was performed to compare west and east coast LineString mean lengths, as a statistical test would only make sense for sample data, as opposed to population parameters.

Finally, to assess the amount of land-filling performed in Okinawa Island in the last 51 years, historical aerial photography data from 1977 were acquired from the Okinawa Prefectural Government GIS webpage (Okinawa Prefectural Government 2019b) and georeferenced. The tracts of coastline that differed from year 2018 were manually traced as vectors using QGIS. The total amount of land added by reclamation activities was obtained by subtracting the area of

Okinawa Island in 1977 from that of Okinawa Island in 2018. Maps figures were generated using the QGIS PDF vector export function.

\section{Results}

The length of the coastline layer imported from the OSM dataset was $656.9 \mathrm{~km}$, with an average node distance (spatial resolution) of $24 \mathrm{~m}$. After adding the most recent coastal 
252 developments, the total coastline reached $682.8 \mathrm{~km}$, at the same spatial resolution. $431.8 \mathrm{~km}$ of 253 coastline were altered, equal to $63.2 \%$ of the total length, leaving $251.0 \mathrm{~km}$ in a natural state $254(36.8 \%)$. The most common category of coastal alteration, in terms of length in $\mathrm{km}$, was land255 filling $(309.2 \mathrm{~km}, 45.3 \%)$, followed by hard armoring $(98.9 \mathrm{~km}, 14.5 \%)$, and then soft armoring 256 (23.7 km, 3.4\%) (Fig. 3).

257 The west coast $(347.5 \mathrm{~km})$ was the most affected by coastal development: $251.4 \mathrm{~km}$ were 258 altered (72.3\%), of which $186.3 \mathrm{~km}$ by land-filling (53.6\%), $52.8 \mathrm{~km}$ by hard armoring (15.2\%), 259 and $12.2 \mathrm{~km}$ by soft armoring (3.5\%). $96.1 \mathrm{~km}$ were in a natural state, equal to $27.7 \%$ of the total 260 length of the west coast. The east coast $(335.3 \mathrm{~km})$ was relatively more preserved: $180.5 \mathrm{~km}$ 261 were altered (53.8\%), of which $122.9 \mathrm{~km}(36.6 \%)$ were altered by land-filling, $46.1 \mathrm{~km}(13.7 \%)$ 262 by hard armoring, and $11.5(3.4 \%)$ by soft armoring. $154.8 \mathrm{~km}(46.2 \%)$ were still in a natural 263 state (Fig. 4).

264 Regarding habitat fragmentation, the number of LineStrings associated with coastal 265 alterations was 427 , meaning there were overall 427 distinct sectors of the coastline, of variable 266 length, presenting human-made alterations and contributing to the fragmentation of the natural coast. Of these, 229 were on the west coast and 198 on the east coast. Interestingly, while landfilled LineStrings had the largest mean length (169 LineStrings, mean length $=1.83 \mathrm{~km}$, sd $=$ $4.27 \mathrm{~km})$, armored tracts with no land-filling, although shorter, were more numerous (258 LineStrings, mean length $=0.48 \mathrm{~km}$, sd $=0.54 \mathrm{~km}$; see Table 1 for split data between soft and hard armoring).

272

The natural coastline was composed of 238 LineStrings. The mean length of natural LineStrings was $1.05 \mathrm{~km}(\mathrm{sd}=1.78 \mathrm{~km})$. In other words, on average, a tract of natural coastline in Okinawa Island was found to be interrupted by coastal armoring or land-filling every $1.05 \mathrm{~km}$.

275 The natural coastal environment was more fragmented in the west coast, where $96.1 \mathrm{~km}$ were 276 composed of 129 distinct LineStrings (mean length $=0.75 \mathrm{~km}, \mathrm{sd}=1.08 \mathrm{~km}$ ). The east coast had

277 instead lower levels of fragmentation: 109 LineStrings for $154.8 \mathrm{~km}$ of natural coastline (mean 278 length $=1.42 \mathrm{~km}, \mathrm{sd}=2.31 \mathrm{~km}$ ). Overall, in the west coast, the natural coastline was composed 279 of more LineStrings of shorter mean length, and therefore was more affected by habitat 280 fragmentation (Fig. 5 and, for a summary of coastal alteration and fragmentation data, Table 1). The longest tract of uninterrupted natural coastline $(10.71 \mathrm{~km})$ was measured in the northeast area of the island, in the Kunigami District (GPS = 26.844964, 128.296063 - 
283 26.794411, 128.317441). The same area hosted two additional tracts of similar length $(\sim 10 \mathrm{~km})$.

284 The northeast of the island, from Teima, Oura Bay (GPS = 26.552018, 128.065038), to Cape

285 Hedo (GPS = 26.875525, 128.257702), was overall the most preserved, with $82.7 \%$ of the

286 coastline in a natural state $(84.96 / 102.70 \mathrm{~km})$. This same area also hosted the majority of natural

287 coastline tracts above $5 \mathrm{~km}$ ( 8 out of 10 totals, 9 of which were on the east coast. Fig. 5). For the

288 west coast, the longest tract of uninterrupted natural coastline $(6.67 \mathrm{~km})$ was in the Nakijin Area

$289(\mathrm{GPS}=26.703180,127.934848-26.696041,127.971799)$ with no other tracts above $5 \mathrm{~km}$ in

290 length.

291 The area of Okinawa Island at the end of year 2018 was measured at $1213.35 \mathrm{~km}^{2}, 5.35$

292 square kilometers more than reported in the Japan Statistical Yearbook (2014). This number

293 includes land-fills detached from the main coastline (from $\sim 100 \mathrm{~m}$ to $\sim 1000 \mathrm{~m}$ distance from

294 shore), and connected to it via multiple bridges: on the west coast the Toyosaki land-fill

295 (Tomigusuku; $1.41 \mathrm{~km}^{2} ;$ GPS $=26.156254,127.654746$ ), on the east coast, from north to south,

296 the Suzaki land-fill $\left(3.47 \mathrm{~km}^{2}\right.$; GPS $\left.=26.333432,127.855115\right)$, the Awase land-fill (measured at

$2970.93 \mathrm{~km}^{2}$, reclamation works still ongoing; GPS $\left.=26.303966,127.840715\right)$, and the

298 Agarihama/Agarizaki land-fill $\left(1.14 \mathrm{~km}^{2}\right.$; GPS $\left.=26.207607,127.765247\right)$. In 1977, the measured

299 area was $1192.32 \mathrm{~km}^{2}$. Hence, the island's expansion, accountable to the land-filling projects

300 performed over a period of 51 years, was measured at $21.03 \mathrm{~km}^{2}$, the majority of which have

301 occurred in the southern part of the island on both the east and west coasts: $18.83 \mathrm{~km}^{2}$, or $\sim 90 \%$

302 of the land-filled area was located south of the Tancha, Onna Village and Yaka, Kin Town

303 districts (Fig. 6). On the west coast, the area surrounding Naha, the prefectural capital has been

304 particularly affected by coastal land-filling: from Itoman (GPS $=26.114724,127.664448)$ to the

305 Kadena US military base (GPS $=26.339156,127.746935)$ the entire coastline $(112.2 \mathrm{~km})$ was

306 altered, and $107 \mathrm{~km}$ of its length were categorized as land-filled ( 95\%).

\section{Discussion}

308 The results of this study revealed that over $63 \%$ of the original Okinawan coastline has

309 been lost or altered by numerous coastal engineering projects, and that what remains is now

310 fragmented into numerous segments divided by land-filled and armored tracts.

311 Land-filling, or land reclamation, was found to be the main contributor to the amount of

312 coastline alterations ( $45 \%$ of the total coastline), especially in the highly urbanized south of the 
313 island, where the capital city Naha and most of the population are located. Reclamation is a

314 direct cause of habitat loss, in particular for coral reefs and mangrove meadows. Although

315 habitat loss as a problem is not unique to Okinawa, the situation in Okinawa Island is

316 noteworthy, for at least two reasons: between 1993 and 1998, the largest increase (47.99\%) in the

317 amount artificial coastline in Japan occurred in Okinawa Prefecture (Biodiversity Center of

318 Japan, Ministry of the Environment 1998). Secondly, unlike mainland Japan, Okinawa Island is

319 subtropical, characterized by the presence of a well-developed fringing reef along its coastline

320 (Reimer et al. 2019). Construction has mainly happened in the shallow waters of the inner reef,

321 over lagoons and reef flats. Being located in the vicinity of river mouths or in the inner reef,

322 mangrove forests and seagrass meadows have also been targets of development. In a coral reef

323 environment, reef formations themselves are an important element in the protection of the

324 coastline: according to Ferrario et al. (2014), coral reefs can provide significant protection from

325 storms, dissipating on average $97 \%$ of wave energy. The economic benefit of the coastal

326 protection provided by Japanese coral reefs has been estimated to be of 172 million USD/year

327 (Cesar, Burke and Pet-Soede 2003), but by reclaiming shallow reefs, this ecosystem service is

328 inevitably lost, leaving the coastline more vulnerable and in need of artificial protection.

329 Similarly, seagrass meadows and mangrove forests are known to provide important

330 ecosystem services: both, particularly seagrass meadows, act as nurseries for valuable fish

331 species (Whitfield 2016 provides a review on the topic). Moreover, mangrove forests offer

332 valuable protection from coastal disasters by significantly reducing economic and human life

333 losses during storms and tsunamis (Das and Vincent 2009). Kathiresan and Rajendran (2005)

334 suggested the adoption of a dense buffer zone made of mangroves and other coastal vegetation of

335 at least $1 \mathrm{~km}$ between the ocean and the first human settlements at Parangipettai, Tamil Nadu,

336 India. However, in Okinawa Island, numerous roads and buildings have been built just a few

337 meters from the coastline. Several coastal roads have suffered the effects of erosion or damage

338 due to their proximity to the ocean. In a few cases, access had to be restricted, or expensive

339 repairs and improvements have been required for the road to remain functional, usually in the

340 form of additional armoring (Nakano 2004). In the northwestern part of the island, despite this

341 being a rural area of low population density (0-100 residents/ $\mathrm{km}^{2}$; Okinawa Prefectural

342 Government 2019b) with abundant space available to build roads, National Route 58 runs for

343 kilometers just a few meters from the coastline (Fig. 2c). This route was built so close to the 
344 ocean that it required the employment of hard armoring, usually in the forms of seawalls and

345 Tetrapods, tetrahedral blocks of various sizes made of concrete placed in front of seawalls or

346 piled up to form breakwaters (Hesse 2007). This combination of coastal roads coupled with

347 seawalls and concrete blocks have altered several tracts of natural coastline in Okinawa Island.

348 In the case of National Route 58 and also in the north Kunigami Area, the artificial landscape

349 extends, with only sporadic interruptions, from the northern part of the Motobu Peninsula (GPS:

350 26.630022, 128.029791) until Ginama Fishing Port (GPS: 26.848042, 128.253570), after which

351 the route deviates from the shoreline. In the same northern region, but on the east coast, National

352 Route 70 connects the north and the south of the island. Because National Route 70 was built

353 inland, leaving a buffer space of vegetation between the road itself and the shoreline, the natural

354 profile of the original coastline has been largely preserved (Fig. 2a). This is an important

355 example of how different engineering approaches to similar problems can affect the environment

356 in different ways. The different state of the east and west coasts of the north Kunigami Area

357 shows that it is possible to build roads without sacrificing the natural coastline. In a subtropical

358 island where tourism is the most important economic asset, and the local government aspires to

359 become a World Natural Heritage Site (Okinawa Prefectural Government 2019c), there should

360 be a strong government interest in limiting the loss of beaches and natural scenery.

$361 \quad$ Although coastal armoring exerts impacts on the natural environment (Seitz et al. 2006;

362 Sane et al. 2007; Dugan et al. 2008; Dethier, Toft and Shipman 2016; Gittman et al. 2016;

363 Aguilera 2017), beyond habitat loss and fragmentation it is unclear how it can affect the general

364 health of a coral reef ecosystem, or how communities inhabiting the surroundings of coastal

365 armoring compare with those inhabiting natural areas. If artificial barriers actively harm corals

366 and the wider coral reef community, then armoring a coastline would mean, in the long term, an

367 increase in artificial defense at the expense of the protection already naturally provided by the

368 reef. Therefore, future research should investigate in detail how shoreline armoring affects

369 coastal ecosystems. Japan is an ideal candidate for such study, as Tetrapods have been widely

370 deployed across different prefectures (Kerr 2001), and yet very little international peer-reviewed

371 studies on their effects on marine communities have been published. It is clear that more research

372 is needed to fill gaps in our knowledge, on this issue and with other coral reef conservation

373 concerns in the region (Reimer et al. 2019). 
The overall benefits of the Japanese coral reefs have been estimated as equivalent to 1665

375

376

377

378

379

380

381

382

383

384

385

386

387

388

389

390

391

392

393

394

395

396

397

398

399

400

401

402

403 million USD/year (Cesar, Burke and Pet-Soede 2003). Realizing the importance of a healthy reef ecosystem, since 2012, the Okinawa Prefectural Government has been investing significant resources in coral reef restoration (6.25 million USD for the first three years of implementation; Okubo and Onuma 2015). However, reef restoration still provides benefits estimated to be six orders of magnitude lower than the amount of damage occurring (Okubo and Onuma 2015), and restoration results are often uncertain and, in some cases, counterproductive (Casey et al. 2015). For these reasons, as progress is made in restoration research and public money is invested on the effort, it is important to also better integrate conservation concerns into development plans in order to spare reefs from further destruction. Finally, it is noteworthy, in this context, that the national action plan for the conservation of Japanese coral reef ecosystems (Ministry of the Environment of Japan 2010) mentions coastal development as a cause of habitat loss and coral reef mortality, and proposes the establishment of Marine Protected Areas (MPAs) and national parks in coral reef regions as a solution. However, as of June 2019, no Marine Protected Area exists in Okinawa Island.

\section{Conclusions}

The coast of Okinawa Island has been subject to significant alterations leading to habitat loss (63.2\% of the coastline artificially altered) and fragmentation (remaining coastline divided in 239 distinct tracts of mean length $=1.05 \mathrm{~km}$ ). As hypothesized, the west coast has been the most impacted by human development.

It is our opinion that the northeast Kunigami coast of the island should be considered as an MPA candidate, being located in an area of low human population, with a relatively pristine coastline, both in terms of amount and fragmentation, and with a biodiversity that is still largely understudied (Reimer et al. 2019).

In the future, coastal restoration/rehabilitation initiatives will need to be evaluated. We live in an era of unprecedented attention to environmental issues. In Singapore, a country where less than $20 \%$ of the coastline remains natural, mangroves have been planted with the intent of rehabilitating artificial habitats (Lai et al. 2015) and research has been made to create more variable armored intertidal zones (Loke et al. 2014; Loke et al. 2015). Several states in the US, such as North and South Carolina, have restricted or banned the use of additional coastal 
404 armoring and are planning or have performed block removals (Kerr 2001; Miller et al. 2012;

405 Dethier, Toft and Shipman 2016). The "soft armoring" category of our map includes several 406 locations where restoration activities could be feasible. In some instances (Fig. 2c) such works

407 would be limited to the removal of old walls no longer used, reducing habitat fragmentation and

408 restoring connectivity between land and ocean. Such restoration activities would benefit species

409 that depend on ocean-land connectivity and have been impacted by habitat loss and

410 fragmentation, like sea turtles for their nesting (Rizkalla and Savage 2010), and coconut crabs to

411 release fertilized eggs (Sato and Yoseda 2013). Walls and barriers built years ago to protect

412 buildings that are now abandoned, or roads no longer used and overgrown by vegetation could

413 also be included in similar initiatives. It is anticipated this work will focus attention on the

414 current status of the Okinawa Island coastline and be utilized as a tool for further evaluations and

415 monitoring, tracking changes in time and allowing comparisons with other regions, in Japan or 416 abroad.

\section{Acknowledgments}

418 The authors would like to thank Masaru Mizuyama for his suggestions that greatly contributed to

419 the improvement of this work, Zax Zeng from Duwei Technology for providing help on

420 acquiring and geotagging historical aerial photography data, Kohei Hamamoto for his help in

421 translating parts of the cited Japanese literature, and Piera Biondi for her comments on early

422 versions of the manuscript. We would like to thank the OpenStreetMap, QGIS and R software

423 communities, whose hard work made this research possible. Comments and suggestions from Dr.

424 Mariko Abe and two anonymous reviewers greatly improved an earlier version of this work. 
425 References

426 - Aguilera, M. A. (2017). Artificial defences in coastal marine ecosystems in Chile:

427 Opportunities for spatial planning to mitigate habitat loss and alteration of the marine 428 community structure. Ecological Engineering, 120, 601-610.

429 - Biodiversity Center of Japan, Ministry of the Environment. 1998. 5th basic survey on 430 conservation of natural environment. http://www.biodic.go.jp/kiso/99/umibe.html [10 $431 \quad$ November 2018, in Japanese].

432 - Casey, J. M., Connolly, S. R., \& Ainsworth, T. D. (2015). Coral transplantation triggers

433 shift in microbiome and promotion of coral disease associated potential pathogens.

$434 \quad$ Scientific Reports, 5(January), 11903.

435 - Cesar, H., Burke, L., \& Pet-Soede, L. (2003). The economics of worldwide coral reef 436 degradation. Cesar environmental economics consulting (CEEC).

437 - Chou, L., Yu, J. \& Loh, T. Impacts of sedimentation on soft-bottom benthic communities 438 in the southern islands of Singapore. Hydrobiologia, 515, 91-106.

439 - Cowman P. F., Parravicini V., Kulbicki M., \& Floeter S. R. (2017). The biogeography of 440 tropical reef fishes: endemism and provinciality through time. Biological Reviews, 92, $441 \quad 2112-2130$

442 - Das, S., \& Vincent, J. R. (2009). Mangroves protected villages and reduced death toll 443 during Indian super cyclone. Proceedings of the National Academy of Sciences, 106(18), $444 \quad 7357-7360$.

445 - Dethier, M. N., Toft, J. D., \& Shipman, H. (2017). Shoreline armoring in an inland sea:

446 Science-based recommendations for policy implementation. Conservation Letters, 10(5), $447 \quad 626-633$.

448 - Dikou, A., van Woesik, R. (2006). Survival under chronic stress from sediment load:

449 spatial patterns of hard coral communities in the southern islands of Singapore. Marine $450 \quad$ Pollution Bulletin, 52 (1), 7-21.

451 - Doody, J. P. (2004). 'Coastal squeeze' - an historical perspective. Journal of Coastal 452 Conservation, 10(1), 129-138.

453 - Dugan J. E., Hubbard D. M., Rodil I. F., Revell D. R., Schroeter S. (2008). Ecological 454 effects of coastal armoring on sandy beaches. Marine Ecology, 29(s1), 160-170. 
455 - Duwei Technology. 2019. https://duweis.com/en/mapplus.html [02 Jan 2019].

456 - Ferrario, F., Beck, M. W., Storlazzi, C. D., Micheli, F., Shepard, C. C., \& Airoldi, L.

457 (2014). The effectiveness of coral reefs for coastal hazard risk reduction and adaptation.

$458 \quad$ Nature Communications, 5, 1-9.

459 - Flyteam Japan. 2013. https://flyteam.jp/news/article/19108 [08 April 2019, in Japanese].

460 - GFC, Kansas State University. 2019. Spatial data analysis, scale and distance.

461 https://rspatial.org/analysis/2-scale_distance.html [18 June 2019].

462 - Gittman, R. K., Peterson, C. H., Currin, C. A., Fodrie, F. J., Piehler, M. F., Bruno, J. F.,

463 ... Bruno, J. F. (2016). Living shorelines can enhance the nursery role of threatened

464 estuarine habitats. Ecological Applications, 26(1), 249-263.

465 - Griggs, B., Tait, J. F., \& Corona, W. (1994). The interaction of seawalls and beaches:

466 seven years of monitoring, Monterey Bay, California. Shore and Beach, 67(3), 21-28.

467 - Haklay, M., \& Weber, P. (2008). OpenStreet map: User-generated street maps. IEEE

468 Pervasive Computing, 7(4), 12-18.

469 - Heery, E. C., Hoeksema, B. W., Browne, N. K., Reimer, J. D., Ang, P. O., Huang, D., ...

470 Todd, P. A. (2018). Urban coral reefs: degradation and resilience of hard coral

$471 \quad$ assemblages in coastal cities of East and Southeast Asia. Marine Pollution Bulletin, 135,

$472 \quad 654-81$.

473 - Hesse, S. (2007). Loving and loathing Japan's concrete coasts, where tetrapods reign.

474 The-Asia-Pacific Journal, Japan Focus, 5(7), 1-9.

475 - Hormann, C. 2013. Assessing the OpenStreetMap coastline data quality.

476 http://www.imagico.de/map/coastline_quality_en.php [18 June 2019].

477 - Japan Statistics Bureau. 2014. Japan Statistical Yearbook 2014. 1-1 Islands, area and

478 major islands of national land.

479 https://www.stat.go.jp/english/data/nenkan/68nenkan/1431-01.html [08 April 2019].

480 - Kathiresan, K., \& Rajendran, N. (2005). Coastal mangrove forests mitigated tsunami.

481 Estuarine, Coastal and Shelf Science, 65(3), 601-606.

482 - Kerr, A. (2001). Dogs and demons: Tales from the dark side of Japan. Macmillan.

483 - Kingston, J. (2005). Downsizing the Construction State. Japanese Economy, 32(4), 3648495. 
485 - Lai, S., Loke, L. H. L., Hilton, M. J., Bouma, T. J., \& Todd, P. A. (2015). The effects of 486 urbanisation on coastal habitats and the potential for ecological engineering: A Singapore 487 case study. Ocean and Coastal Management, 103, 78-85.

488 - Loke, L. H., Jachowski, N. R., Bouma, T. J., Ladle, R. J., \& Todd, P. A. (2014).

489 Complexity for Artificial Substrates (CASU): software for creating and visualising $490 \quad$ habitat complexity. PLoS One, 9(2), e87990.

491 - Loke, L. H., Ladle, R. J., Bouma, T. J., \& Todd, P. A. (2015). Creating complex habitats 492 for restoration and reconciliation. Ecological Engineering, 77, 307-313.

493 - Mandelbrot, B. (1967). How long is the coast of Britain? Statistical self-Similarity and 494 fractional dimension. Science, 156(3775), 636-638.

495 - McCormack, G. (1998). Okinawan Dilemmas: Coral Islands or concrete Islands. JPRI

496 Working Paper, 45 http://www.jpri.org/publications/workingpapers/wp45.html [06

497 March 2019].

498 - McCormack, G. (1999). From the sea that divides to the sea that links: Contradictions of 499 ecological and economic development in Okinawa. Capitalism, Nature, Socialism, 10(1), 500 3-39.

501 - Miller K. L., Holstead J. R., DeBoer H., Randall M. 2012. Seawall construction laws in 502 east coast states. https://www.cga.ct.gov/2012/rpt/2012-R-0074.htm [18 May 2019].

503 - Ministry of the Environment of Japan. 2010. The action plan to conserve coral reef 504 ecosystem in japan. For the prosperity of current and future communities derived from a $505 \quad$ lasting healthy natural environment.

506 - https://www.env.go.jp/nature/biodic/coralreefs/pamph/pamph_full-en.pdf [09 March 507 2019].

508 - Ministry of Land, Infrastructure and Transport of Japan. 2001. List of procedures (law for 509 the land-filling of public waters). https://www.mlit.go.jp/onestop/042/042_.html [20 June $510 \quad 2019$, in Japanese].

511 - Ministry of the Environment of Japan. 2019. Environmental impact assessment in Japan. 512 https://www.env.go.jp/en/policy/assess/pamph.pdf?fbclid=IwAR3xPFiEfhtABXQT0FPo 513 0e7GZHuqfvH24y475dMUghqZThVqEn7gZm-k76o/ [09 March 2019]. 
514 - Nakano, Y. (2004). Direct impacts of coastal development. In Ministry of the

515 Environment, \& Japanese Coral Reef Society (Eds.), in: Coral Reefs of Japan (Chapter 2,

516 pp. 60-63.), Tokyo, Japan: Ministry of the Environment.

517 - Nam K. (Translated by Lee, M. J., Nam, K., and Engel, B. A.) (2019). Is the postwar

518 state melting down?: an East Asian perspective on post-Fukushima Japan, Inter-Asia

519 Cultural Studies, 20:1, 91-106,

520 - Nishihira, M. (2004). Hermatypic corals of Japan. In Ministry of the Environment, \&

521 Japanese Coral Reef Society (Eds.), Coral Reefs of Japan (Chapter 1, pp. 10-13.), Tokyo,

522 Japan: Ministry of the Environment.

523 - Okinawa Defense Bureau. 2012. Environmental impact assessment book (abstract book)

524 pertaining the Futenma Airfield alternative facility construction project, chapter $2(1 / 5)$.

525 https://www.mod.go.jp/rdb/okinawa/07oshirase/chotatsu/hyoukayouyaku/252.pdf [19

526 June 2019, in Japanese].

527 - Okinawa Prefectural Government. 2014. License for the land-filling of public waters.

528 https:/www.pref.okinawa.jp/site/norin/gyokogyojo/kanri/documents/menkyo_tetuduki2.

529 pdf [20 June 2019, in Japanese].

530 - Okinawa Prefectural Government. 2019a. Population estimates.

531 https://www.pref.okinawa.jp/toukeika/estimates/estimates_suikei.html [19 June 2019].

532 - Okinawa Prefectural Government. 2019b. GIS webpage. http://gis.pref.okinawa.jp/ [08

533 May 2019, in Japanese].

534 - Okinawa Prefectural Government. 2019c. Aiming to Become a Natural World Heritage.

535 https:/www.pref.okinawa.jp/site/chijiko/kohokoryu/foreign/english/documents/a_imingt

536 o_become_a_naturale_world_heritage.pdf [28 May 2019].

537 - Okubo, N., \& Onuma, A. (2015). An economic and ecological consideration of

538 commercial coral transplantation to restore the marine ecosystem in Okinawa, Japan.

539 Ecosystem Services, 11, 39-44.

540 - Powter, C. B. (Compiler) (2002). Glossary of Reclamation and Remediation Terms Used

541 in Alberta - 7th Edition, Alberta Environment, Science and Standards Branch,

542 Edmonton, Alberta. Pub. No. T/655; Report No. SSB/LM/02-1. 88 pp.

543 - QGIS Geographic Information System. Open source geospatial foundation project.

544 http://qgis.osgeo.org [04 May 2018]. 
545 - R Development Core Team. 2019. R: A language and environment for statistical

546 computing. R Foundation for Statistical Computing. Vienna, Austria.

547 - Reimer, J. D., Yang, S. Y., White, K. N., Asami, R., Fujita, K., Hongo, C., ... Jenke-

548 Kodama, H. (2015). Effects of causeway construction on environment and biota of

549 subtropical tidal flats in Okinawa, Japan. Marine Pollution Bulletin, 94(1-2), 153-167.

550 - Reimer, J. D., Biondi, P., Lau, Y. W., Masucci, G. D., Nguyen, X. H., Santos, M. E., \&

551 Wee, H. B. (2019). Marine biodiversity research in the Ryukyu Islands, Japan: Current

$552 \quad$ status and trends. PeerJ, 7, e6532.

553 - Richardson L. F. (1961). The problem of contiguity: an appendix to statistics of deadly

554 quarrels. General Systems Yearbook, 6, 139-87.

555 - Rizkalla, C. E., \& Savage, A. (2010). Impact of seawalls on loggerhead sea turtle

556 (Caretta caretta) nesting and hatching success. Journal of Coastal Research, 27(1), 166-

$557 \quad 173$.

558 - Ryukyu Shimpo. 2018. http://english.ryukyushimpo.jp/2018/02/08/28457/ [02 March

559 2019].

560 - Sane, M., Yamagishi, H., Tateishi, M., \& Yamagishi, T. (2007). Environmental impacts

561 of shore-parallel breakwaters along Nagahama and Ohgata, District of Joetsu, Japan.

562 Journal of Environmental Management, 82(4), 399-409.

563 - Sato, T., \& Yoseda, K. (2013). Reproductive migration of the coconut crab Birgus latro.

$564 \quad$ Plankton and Benthos Research, 8(1), 49-54.

565 - Seitz, R. D., Lipcius, R. N., Olmstead, N. H., Seebo, M. S., \& Lambert, D. M. (2006).

566 Influence of shallow-water habitats and shoreline development on abundance, biomass,

567 and diversity of benthic prey and predators in Chesapeake Bay. Marine Ecology Progress

$568 \quad$ Series, 326, 11-27.

569 - Tada, O. (2015). Constructing Okinawa as Japan’s Hawai ‘i: From honeymoon boom to

$570 \quad$ resort paradise. Japanese Studies, 35(3), 287-302.

571 - Walker, H. J., \& Mossa, J. (1986). Human modification of the shoreline of Japan.

$572 \quad$ Physical Geography, 7(2), 116-139.

573 - Whitfield, A. K. (2016). The role of seagrass meadows, mangrove forests, salt marshes

574 and reed beds as nursery areas and food sources for fishes in estuaries. Reviews in Fish

$575 \quad$ Biology and Fisheries, 27(1), 75-110. 
Figure 1 (on next page)

Okinawa Island and surrounding areas in southern Japan, northwestern Pacific Ocean.

The map includes locations discussed in this research. 


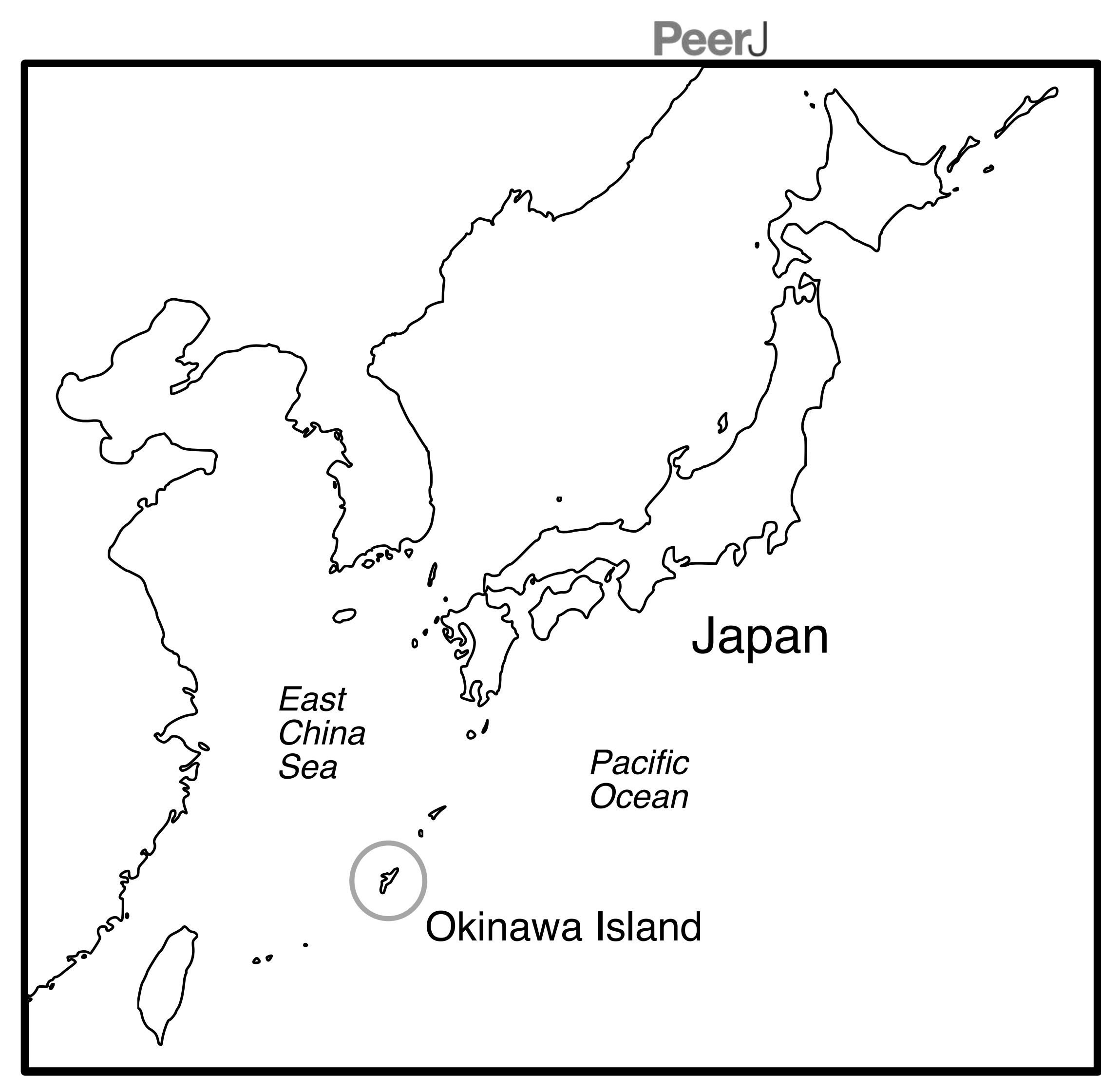

ManUscript to be reviewed

$\bigcup_{B}$

$27^{\circ} \mathrm{N}$

\section{Okinawa Island}

East

China

Sea

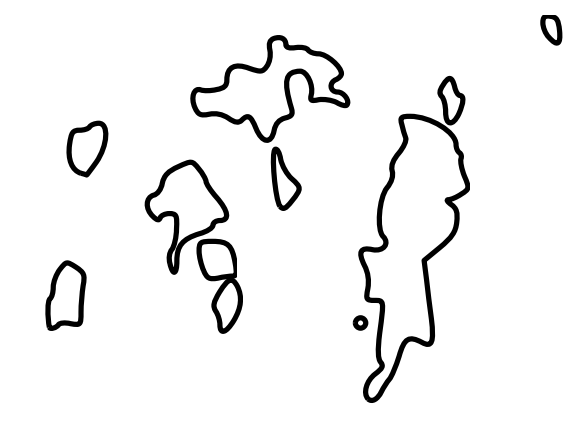

0

$$
\text { 3 }
$$




\section{Figure 2}

Coastline categories.

A) Natural (east Kunigami). Vegetation acts as buffer between shoreline and road. B) Soft armoring (Odo). Beach and vegetation preserved but disconnected due to the presence of human-made structures above the intertidal zone. C) Hard armoring (west Kunigami). Roads or buildings built next to the coastline. Presence of seawalls and/or breakwaters. D) Landfilling (Agarihama/Agarizaki). Shallow waters turned into land to increase the space available for human activities. The yellow line indicates the original shoreline before reclamation. For each category, color choices are consistent with those used in Figure 3. Map data $\odot 2019$ Google. 


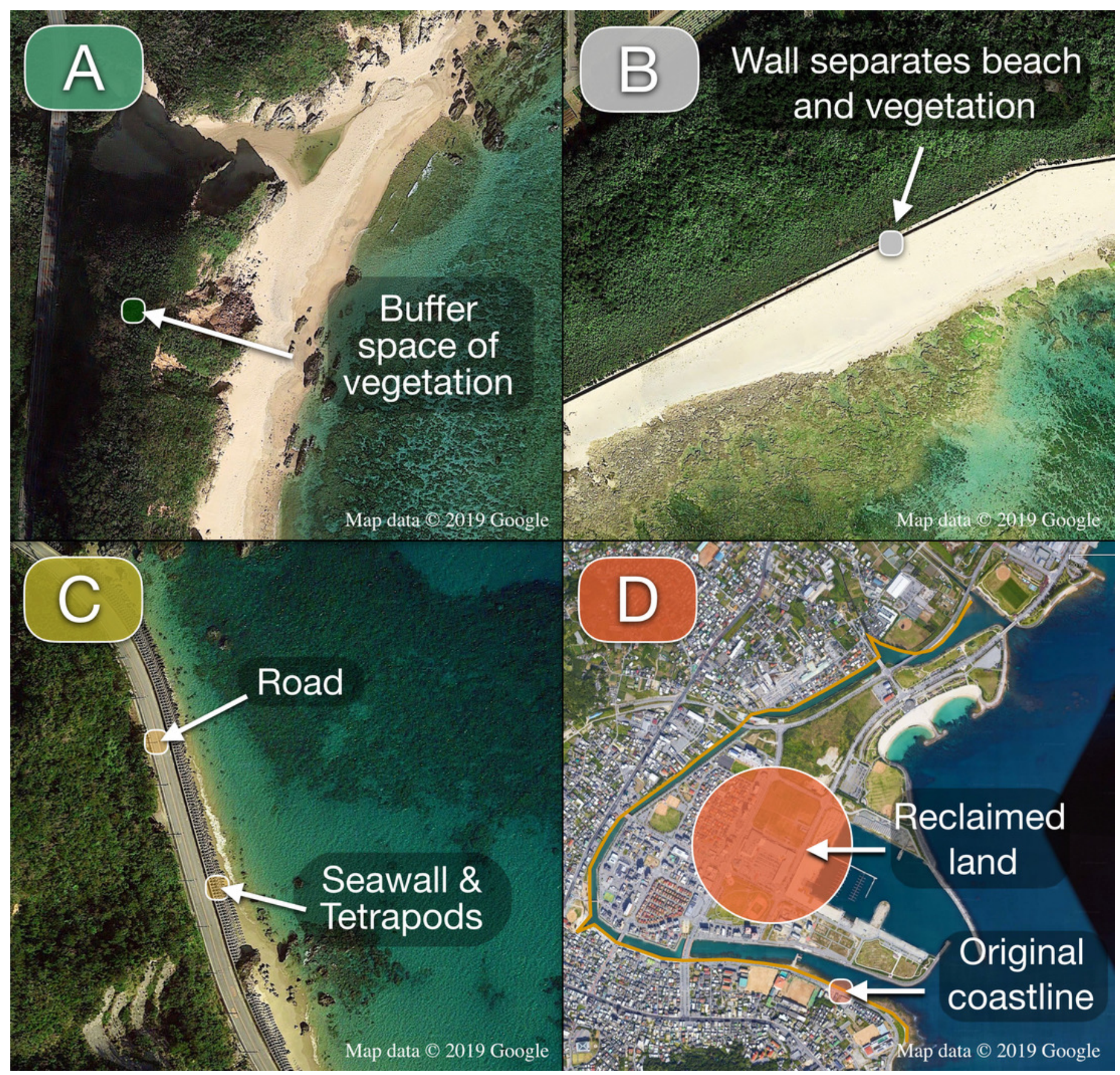




\section{Figure 3 (on next page)}

Map of human-made alterations to the Okinawa Island coastline.

Different alteration categories are represented by different colors and summarized in the pie chart, which shows their relative abundances (\%). Base layer map data (c) OpenStreetMap contributors. 


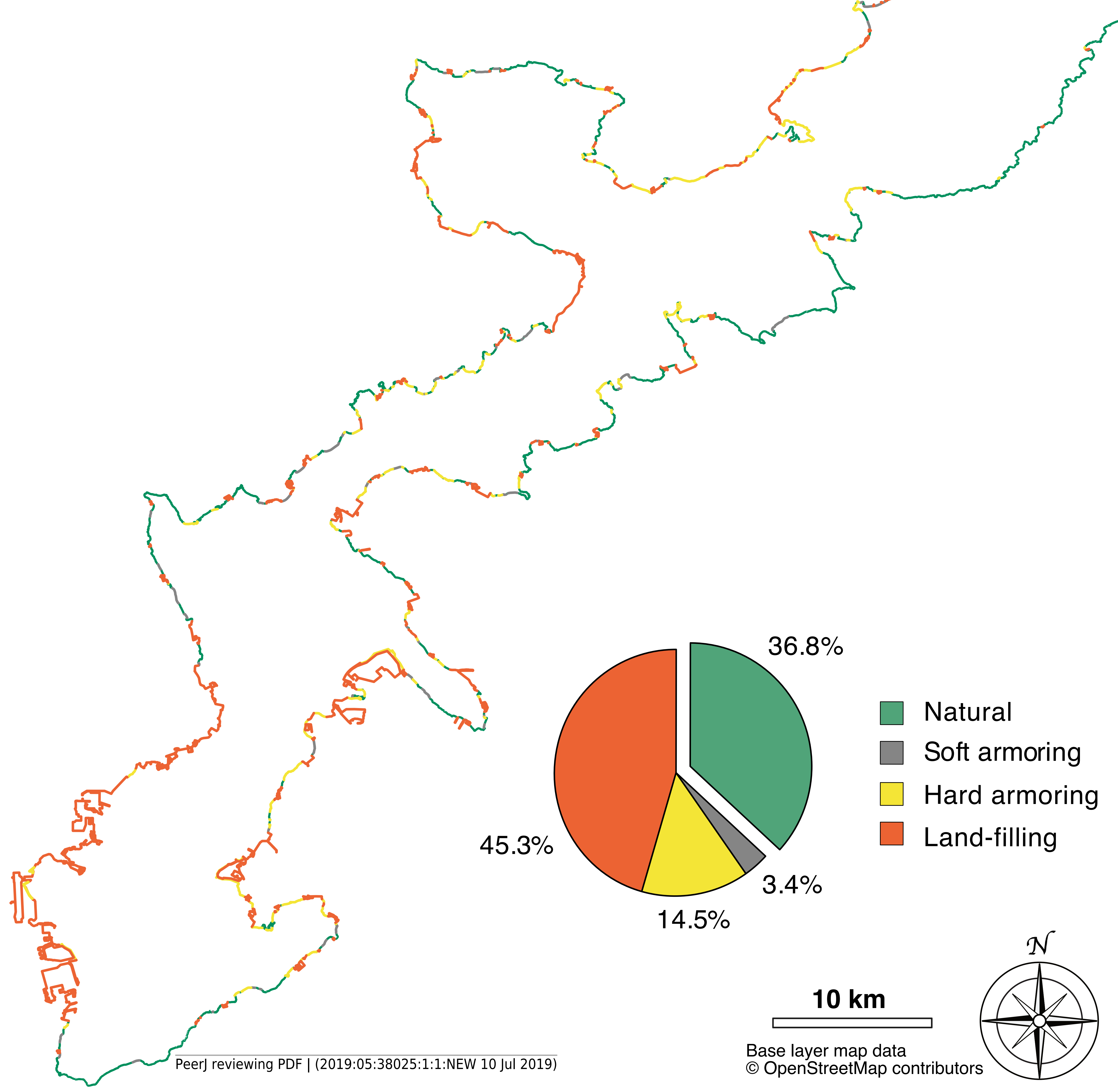


Figure 4 (on next page)

Coastal development categories divided between the east and west coasts of Okinawa Island. 

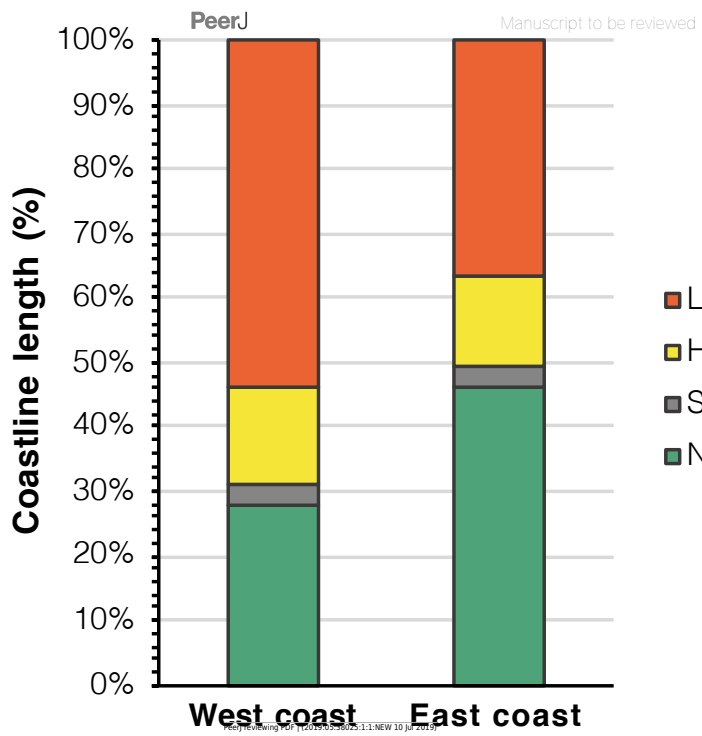

- Land-filling

口Hard armoring

口Soft armoring

口Natural 
Figure $\mathbf{5}$ (on next page)

Natural LineStrings in Okinawa Island and their length $(\mathrm{km})$.

A) West coast. B) East coast. The horizontal dashed line highlights the presence of a single LineString above $5 \mathrm{~km}$ on the west coast, compared to 9 LineStrings for the east coast. 


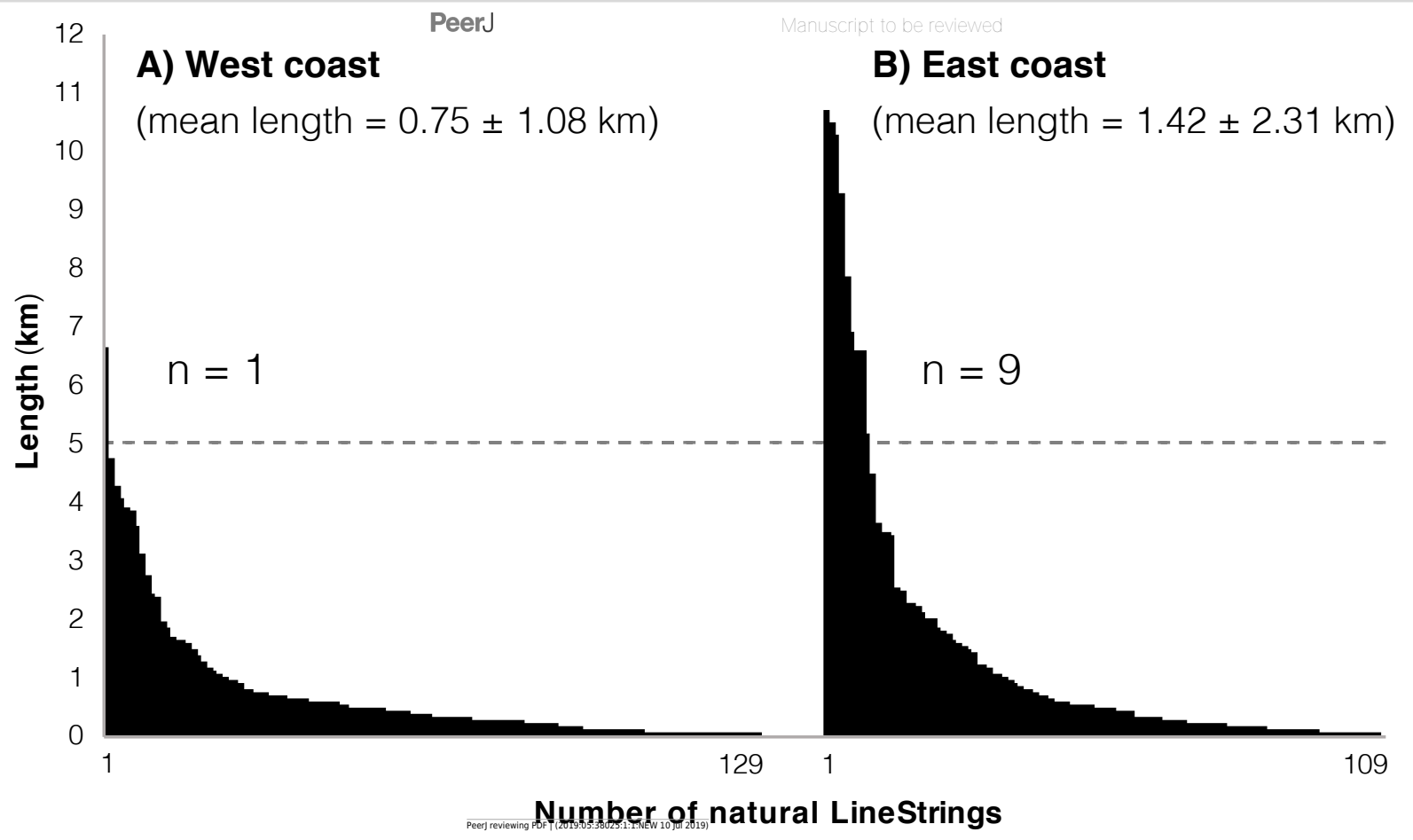


Figure $\mathbf{6}$ (on next page)

Map of the land-filling occurred in Okinawa Island over a period of 51 years (1977-2018).

A) South part of Okinawa Island (south of Tancha and Yaka). Base layer map data (2018) () OpenStreetMap contributors. B) North part of Okinawa Island (north of Tancha and Yaka). The area from 1977 is colored in grey, newer expansions from 2018 are highlighted in red. Base layer map data (2018) @ OpenStreetMap contributors. 


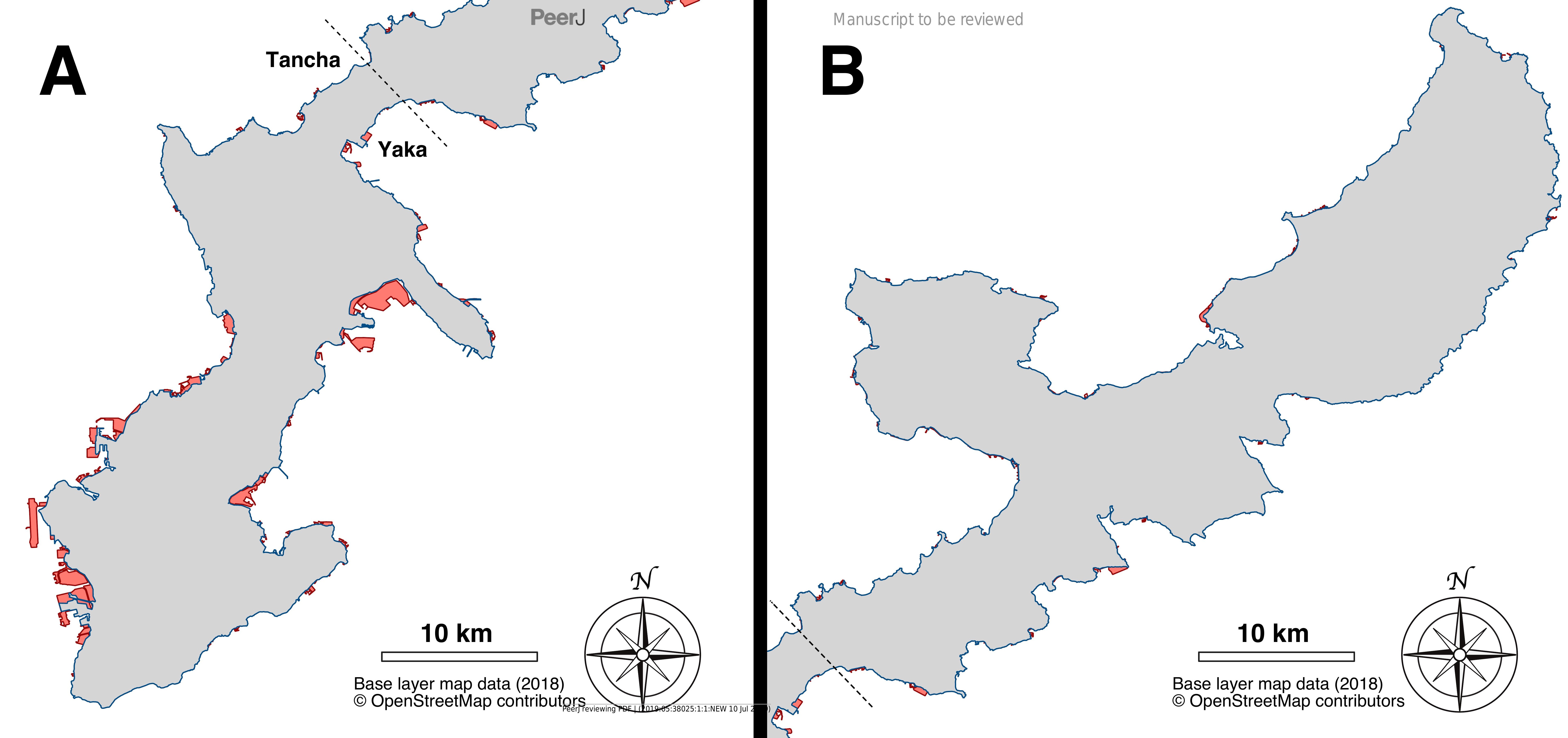




\section{Table $\mathbf{1}$ (on next page)}

Summary of coastal alteration and fragmentation data. 
1

\begin{tabular}{clccccc}
\hline & Natural & $\begin{array}{c}\text { Soft } \\
\text { armoring }\end{array}$ & $\begin{array}{c}\text { Hard } \\
\text { armoring }\end{array}$ & $\begin{array}{c}\text { Land- } \\
\text { filling }\end{array}$ & $\begin{array}{c}\text { Total } \\
\text { altered }\end{array}$ \\
\hline \multirow{3}{*}{ West } & Length $(\mathrm{km})$ & 96.1 & 12.2 & 52.8 & 186.3 & 251.4 \\
& \% of West coast & 27.7 & 3.5 & 15.2 & 53.6 & 72.3 \\
& LineStrings number & 129 & 32 & 110 & 87 & 229 \\
& LineStrings mean length $(\mathrm{km})$ & 0.75 & 0.38 & 0.48 & 2.14 & 1.10 \\
& Standard deviation $(\mathrm{km})$ & 1.08 & 0.29 & 0.62 & 5.66 & 3.60 \\
\hline \multirow{5}{*}{ East } & Length $(\mathrm{km})$ & 154.8 & 11.5 & 46.1 & 122.9 & 180.5 \\
coast & \% of East coast & 46.2 & 3.4 & 13.7 & 36.6 & 53.8 \\
& LineStrings number & 109 & 31 & 85 & 82 & 198 \\
& LineStrings mean length $(\mathrm{km})$ & 1.42 & 0.37 & 0.54 & 1.50 & 0.91 \\
& Standard deviation $(\mathrm{km})$ & 2.31 & 0.31 & 0.55 & 1.90 & 1.37 \\
\hline \multirow{3}{*}{ Total } & Length $(\mathrm{km})$ & 251.0 & 23.7 & 98.9 & 309.2 & 431.8 \\
coastline & \% of Total coastline & 36.8 & 3.5 & 14.5 & 45.3 & 63.2 \\
& LineStrings number & 238 & 63 & 195 & 169 & 427 \\
& LineStrings mean length $(\mathrm{km})$ & 1.05 & 0.38 & 0.51 & 1.83 & 1.01 \\
& Standard deviation $(\mathrm{km})$ & 1.78 & 0.30 & 0.59 & 4.27 & 2.79 \\
\hline
\end{tabular}

